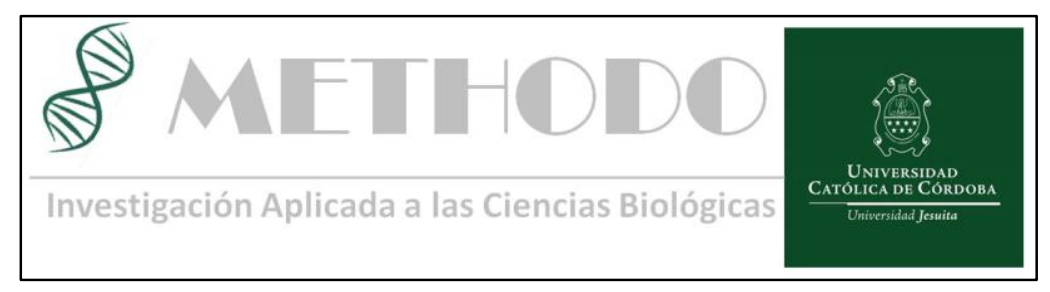

CASO CLINICO Methodo 2019;4(1):27-28

DOI: $10.22529 / \mathrm{me} .2019 .4(1) 07$

Recibido 10 Oct. 2018| Aceptado 29 Ene. 2019| Publicado 29 Mar. 2019

\title{
Encefalopatía epiléptica de inicio temprano, pdch19
}

\section{Epileptic encephalopathy of early start, pdch19}

\author{
María P Vaudagna ${ }^{1}$, Glenda Vergara ${ }^{1-2}$, Ariel Martínez ${ }^{1-2}$, Canonero Ivana ${ }^{2}$, Sfaello Zenón ${ }^{2}$, Sfaello \\ Ignacio $^{1-2}$. \\ 1Servicio de Neurología Infantil, Clínica Universitaria Reina Fabiola. Córdoba Argentina. \\ 2Servicio de Neurología Infantil, Instituto CETES, Córdoba Argentina. \\ Correspondencia: María Paula Vaudagna, Servicio de Neurología Infantil- Clínica Universitaria Reina Fabiola. Oncativo 1248 -X5004FHP- Córdoba, Argentina; \\ email : pauvaudagna@gmail.com
}

\section{Introducción}

La encefalopatía epiléptica infantil precoz 9 o epilepsia restringida a mujeres con o sin retraso mental, es causada por una mutación en el gen que codifica la proteína protocadherina-19 (PCDH19; 300460) en el cromosoma Xq22 $2^{1-2}$. Identificándose en la actualidad 6 mutaciones diferentes en el gen PCDH193. Caracterizado fenotípicamente por encefalopatía epiléptica temprana, múltiples tipos de crisis, asociados con fiebre, retraso mental leve a severo con trastorno del lenguaje y ataxia ${ }^{4}$.Las mutaciones en PCDH19 pueden causar una encefalopatía epiléptica temprana y grave que simula el Síndrome de Dravet, con características clínicas muy similares, incluida la asociación de convulsiones tempranas febriles y afebriles, polimorficas, en salvas, retraso en el desarrollo y el lenguaje, alteraciones del comportamiento y regresión cognitiva ${ }^{5}$.

\section{Objetivo}

Presentación de caso clínico de tres hermanas con encefalopatía epiléptica de inicio precoz.

\section{Caso Clínico}

Niña de 7 años con inicio de epilepsia al año de edad, crisis en salva con clínica variable, desencadenados con cuadros febriles, asociado a retraso madurativo, sin dismorfias, EEG normales, RMN normal, estudios neurometabolicos normales. Se solicita exoma al no evidenciarse dismorfias, el cual se identificó la variante c.1515T $>$ G (p. Tyr505) en el gen PDCH19, considerada patogénica, la niña presenta una buena evolución de su encefalopatía epiléptica con retraso mental moderado y conductas autistas.

Hermanas de cinco y dos años, al año presentan convulsiones en salvas relacionadas a cuadros febriles, segunda hermana retraso mental leve, crisis esporádicas y hermana menor desarrollo acorde a edad, no repite las mismas.

\section{Conclusión}

Tras el cuadro clínico hallado en las tres hermanas se enfatiza en el antecedente de la hermana mayor con la mutación en el gen PCDH19, el cual se asocia con la aparición de convulsiones en la primera infancia, a menudo en salvas, sin evidencia de frecuencia de convulsiones con el grado de déficit cognitivo. PCDH19 es probablemente un gen de epilepsia importante; dado el amplio espectro fenotípico, serán necesarias grandes series de casos para determinarlo. 


\section{Introduction}

Early infantile epileptic encephalopathy 9 or epilepsy restricted to women with or without mental retardation is caused by a mutation in the gene encoding protocadherin-19 protein (PCDH19; 300460) on chromosome Xq22. ${ }^{1-2}$ Currently identifying 6 different mutations in the PCDH $19^{3}$ gene.

Characterized phenotypically by early epileptic encephalopathy, multiple types of seizures, associated with fever, mild to severe mental retardation with language impairment and ataxia. ${ }^{4}$ Mutations in PCDH19 can cause an early and severe epileptic encephalopathy that simulates Dravet syndrome, with very similar clinical characteristics, including the association of febrile and afebrile seizures, polymorphic, in salvas, developmental delay and language, alterations in behavior and cognitive regression ${ }^{5}$.

\section{Objective}

Presentation of a clinical case of three sisters with epileptic encephalopathy of early onset.

\section{Case report}

A 7-year-old girl with onset of epilepsy at 1 year of age, salvage crisis with variable clinical symptoms, triggered by febrile symptoms, associated with maturational delay, without dysmorphisms, normal EEG, normal MRI, normal neurometabolic studies. Exome was requested due to no evidence of dysmorphism, which identified the variant c. $1515 \mathrm{~T}>\mathrm{G}$ (p. Tyr505) in the PDCH19 gene, considered pathogenic, the girl presented a good evolution of her epileptic encephalopathy with moderate mental retardation and autistic behaviors.

Sisters of five and two years, a year have convulsions in salvas related to febrile symptoms, second sister mild mental retardation, sporadic crises and younger sister development according to age, do not repeat them.

\section{Conclusion}

After the clinical picture found in the three sisters, it is emphasized in the antecedent of the older sister with the mutation in the PCDH19 gene, which is associated with the appearance of convulsions in early childhood, often in salvos, without evidence of frequency of seizures with the degree of cognitive deficit.

PCDH19 is probably an important epilepsy gene; given the broad phenotypic spectrum, large series of cases will be necessary to determine it.

\section{Bibliografía}

1. Hoshina M and cools; "A patient with an early diagnosis of PCDH19-related epilepsy"; No To Hattatsu. 2015 Jul;47(4):305-9; PMID: 26353454

2. Dibbens, L. M., and cools; "X-linked protocadherin 19 mutations cause femalelimited epilepsy and cognitive impairment"; Nat Genet. 2008 Jun; 40(6):776-81; DOI: 10.1038/ng.149. Epub 2008 May 11.

3. Tsai MH and cool; "Molecular Genetic Characterization of Patients With Focal Epilepsy Using a Customized Targeted Resequencing Gene Panel"; Front Neurol.2018 Jul 6;9:515. DOI: 10.3389/fneur.2018.00515. eCollection 201.

4. Smith L; "PCDH19-related epilepsy is associated with a broad neurodevelopmental spectrum"; Epilepsia. 2018 Mar; 59(3):679689; DOI: 10.1111/epi.14003. Epub 2018 Jan 28.

5. Depienne, Cand cools; "Sporadic infantile epileptic encephalopathy caused by mutations in PCDH19 resembles Dravet syndrome but mainly affects females"; PLoS Genet. 5: e1000381, 2009. Note: Electronic Article. Erratum: published online;

Https://doi.org/10.1371/journal.pgen.10003 81

\section{Palabras claves}

ENCEFALOPATÍA EPILÉPTICA, PDCH19, PRIMERA INFANCIA, DÉFICIT COGNITIVO

\section{Keywords}

ENCEPHALOPATHY EPILEPTIC, PDCH19, EARLY CHILDHOOD, COGNITIVE DEFICIT.

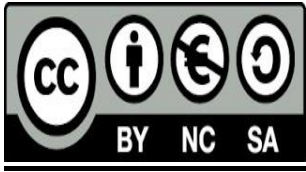

